\title{
Impact of Temperature on In Planta Expression of Genes Involved in Synthesis of the Pseudomonas syringae Phytotoxin Coronatine
}

\author{
Helge Weingart, ${ }^{1}$ Stephan Stubner, ${ }^{2}$ Alexander Schenk, ${ }^{1}$ and Matthias S. Ullrich ${ }^{1}$ \\ ${ }^{1}$ International University Bremen, School of Engineering and Sciences, Campus Ring 1, 28759 Bremen, Germany; ${ }^{2}$ Max- \\ Planck-Institute for terrestrial Microbiology, Karl-von-Frisch-Strasse, 35043 Marburg, Germany
}

Submitted 6 February 2004. Accepted 4 June 2004.

\begin{abstract}
Coronatine (COR) is a chlorosis-inducing phytotoxin produced by the plant-pathogenic bacterium Pseudomonas syringae. Confocal laser scanning microscopy was used to investigate in vitro and in planta expression of COR genes by two model organisms, $P$. syringae pv. glycinea PG4180, a pathogen of soybean, and $P$. syringae pv. tomato $\mathrm{DC3000,}$, pathogen of tomato and crucifers. Previously, it was shown in vitro that the $c m a$ operon involved in COR synthesis in PG4180 is expressed in a temperature-dependent manner, with maximal rates at $18^{\circ} \mathrm{C}$ and low activity at $28^{\circ} \mathrm{C}$. However, nothing was known about the influence of temperature on the expression of COR biosynthetic genes in planta. Therefore, transcriptional fusions of the PG4180 and $\mathrm{DC3000}$ cma promoter regions to a promoterless egfp gene were constructed and expressed in both $P$. syringae strains. The fluorescence patterns in response to temperature during growth of a strain in vitro were consistent with its COR production and the cma transcript abundance as revealed by RNA dot blot hybridization. Quantification of fluorescence indicated that cma promoter activity was dependent on the genetic background of the host strain. Expression of cma::egfp in PG4180 was temperature-dependent in minimal medium as well as inside the plant tissue. In contrast, transcription of the cma operon was not significantly affected by temperature in DC3000. However, cells of DC3000 harboring the cma::egfp fusions showed higher levels of fluorescence when recovered from infected host plants compared with cells grown in minimal medium. These results indicate that the signals for induction of COR biosynthesis differ significantly in PG4180 and DC3000.
\end{abstract}

Coronatine (COR) is a nonhost-specific phytotoxin produced by several pathovars of Pseudomonas syringae (i.e., pvs. alisalensis, atropurpurea, glycinea, maculicola, morsprunorum, porri, and tomato) which infect broccoli, ryegrass, soybean, crucifers, Prunus spp., leek, and tomato, respectively (Bender et al. 1999; Cintas et al. 2002; Koike et al. 1998; Mitchell 1982; Völksch and Weingart 1998). The structure of COR is unusual and consists of two distinct components, the polyketide coronafacic acid (CFA) and a cyclized amino acid, coronamic acid (CMA), derived from isoleucine. CFA and CMA are linked by an amide bond. Both CFA and CMA function as intermediates in the pathway to COR and are se-

Corresponding author: Matthias S. Ullrich; Telephone: +49-421-2003245; Fax: +49-421-2003249; E-mail: m.ullrich@iu-bremen.de creted by COR-producing strains at low levels (Bender et al. 1999; Ichihara et al. 1977; Mitchell et al. 1994).

The primary symptom observed in leaf tissue treated with COR is an intense spreading chlorosis that can be induced on a wide variety of plant species (Gnanamanickam et al. 1982). COR also is known to induce hypertrophy of storage tissue, compression of thyllakoids, thickening of plant cell walls, accumulation of protease inhibitors, inhibition of root elongation, and stimulation of ethylene production in some but not all plant species (Kenyon and Turner 1992; Palmer and Bender 1995; Sakai et al. 1979). Based on structural similarities and the induction of analogous biological responses in plants, COR has been proposed to function as a molecular mimic of methyl jasmonate (MeJA), a plant-growth regulator of the octadecanoid signaling pathway involved in plant defence mechanisms and global cell differentiation processes (Koda et al. 1996; Weiler et al. 1994). Further evidence for a similar mode of action stems from COR-insensitive (coil) mutants of Arabidopsis thaliana and jasmonic acid-insensitive (jail) mutants of tomato showing insensitivity to the effects of both COR and MeJA (Feys et al. 1994; Kloek et al. 2001; Zhao et al. 2003). COR production plays an important role in virulence of toxin-producing $P$. syringae strains. Studies with CORdefective mutants have shown that COR synthesis contributes significantly to lesion expansion, the development of chlorosis, and bacterial multiplication in infected leaves (Bender et al. 1987; Budde and Ullrich 2000; Mittal and Davis 1995).

A variety of environmental and nutritional factors, such as $\mathrm{pH}$, osmolarity, carbon sources, nutrient levels, amino acid supplements, and the presence of complex carbon and nitrogen sources, affect COR production in $P$. syringae (Palmer and Bender 1993; Palmer et al. 1997). In addition, temperature had a highly significant effect on COR biosynthesis in $P$. syringae pv. glycinea $\mathrm{PG} 4180$, with maximal production at $18^{\circ} \mathrm{C}$ and negligible yields at $28^{\circ} \mathrm{C}$, a temperature optimal for growth of $P$. $s y$ ringae (Palmer and Bender 1993). Several studies indicated that temperature directly affected transcriptional activity of the promoters associated with COR production (Liyanage et al. 1995a; Ullrich and Bender 1994; Ullrich et al. 1995). The 32-kb COR gene cluster consists of two regions containing structural genes for CFA and CMA biosynthesis. These are separated by a 3.4$\mathrm{kb}$ regulatory region. Transcriptional fusions of the CFA and CMA promoter region to a promoterless $\beta$-glucuronidase gene showed maximal transcriptional activities at $18^{\circ} \mathrm{C}$ and significantly lower activities at $28^{\circ} \mathrm{C}$ (Liyanage et al. 1995a; Ullrich and Bender 1994).

The regulatory region which controls both CFA and CMA production encodes a modified two-component system con- 
sisting of two response regulators, CorR and CorP, and the histidine protein kinase, CorS (Ullrich et al. 1995). CorR contains a DNA-binding, helix-turn-helix motif and acts as a positive regulator of COR gene expression (Peñaloza-Vázquez and Bender 1998; Wang et al. 1999). CorP is highly similar to CorR but lacks the DNA-binding domain. CorP is required for the activation of CorR by the histidine protein kinase CorS at low temperature. This modified two-component system was able to achieve temperature-dependent activation of an introduced COR biosynthetic promoter in a $P$. syringae strain lacking the COR gene cluster, indicating that this triad of genes has the primary control over COR biosynthesis and is responsible for thermoregulation (Smirnova et al. 2002).

In phytopathogenic bacteria, several classes of genes important for plant-bacteria interactions are induced by plant-derived signals. Well-known examples are the vir genes of Agrobacterium spp., encoding the T-DNA transfer machinery, the syrB gene of $P$. syringae pv. syringae, involved in production of the phytotoxin syringomycin, and the hrp genes of gramnegative phytopathogenic bacteria, encoding a type III secretion machinery (van Gijsegem 1997).

Ma and associates (1991) demonstrated that growth on tomato plants and in a basal medium containing tomato leaf extract strongly activated COR gene expression in $P$. syringae pv. tomato DC3000. Malic and citric acid were identified as active components in tomato leaf extracts responsible for increased expression of COR genes ( $\mathrm{Li}$ et al. 1998). Recently, Boch and associates (2002) used a modified in vivo expression technology (IVET) approach to identify genes from DC3000 that are induced upon infection of A. thaliana. Several of these in planta-expressed promoter fusions were located in the $c f a$ operon. Furthermore, a regulatory link between the expression of the hrp type III secretion system and COR biosynthesis was found in DC3000. The hrp system as such is not required for COR production, but the alternative sigma factor HrpL is able to activate transcription of the CFA operon and, possibly, of CorR controlling COR biosynthesis (Fouts et al. 2002), whereas the regulatory protein $\mathrm{HrpV}$ might negatively control COR synthesis in DC3000 (Peñaloza-Vázquez et al. 2000). In contrast, no influence on COR production was found when the growth medium of $P$. syringae pv. glycinea PG4180 was amended with extracts of soybean and with plant-derived secondary metabolites (Palmer and Bender 1993). These results indicate a different regulation of COR biosynthesis in $P$. syringae pv. glycinea PG4180 and $P$. syringae pv. tomato DC3000. When compared in vitro, COR production by PG4180 is temperature-dependent and approximately 20 -fold higher than that by DC3000. However, both strains produce similar amounts of COR in planta (Zhao et al. 2001).

Taken together, these results raised the question whether the in vitro thermoregulation of COR gene expression in PG4180 also plays a role in planta. Therefore, plasmids containing a transcriptional fusion of the $\mathrm{cma}$ promoter region to a promoterless egfp gene were constructed and introduced into $P$. syringae strains. Confocal laser scanning microscopy (CLSM) was used to investigate in vitro and in planta expression of COR biosynthetic genes by PG4180 and DC3000 at 18 and $28^{\circ} \mathrm{C}$.

\section{RESULTS}

\section{Effect of temperature on COR production in vitro.}

P. syringae strains PG4180 and DC3000 were grown in Hoitink-Sinden minimal medium optimized for COR production (HSC medium) at 18 and $28^{\circ} \mathrm{C}$. To ensure sufficient bacterial growth and maximal COR production at each incubation temperature, cells were incubated for 3 to 5 days until they reached an optical density at $600 \mathrm{~nm}\left(\mathrm{OD}_{600}\right)$ of approximately 5.0 to 6.0 (late stationary phase). Supernatants of the cultures then were analyzed for COR synthesis. P. syringae pv. glycinea $\mathrm{PG} 4180$ produced approximately $30 \mu \mathrm{g}$ of COR per milligram of cell protein at $18^{\circ} \mathrm{C}$, but only $0.5 \mu \mathrm{g}$ of COR per milligram of cell protein at $28^{\circ} \mathrm{C}$, which is the optimal growth temperature. In contrast, COR synthesis by $P$. syringae pv. tomato DC3000 was significantly lower and only slightly affected by temperature, with 1.5-fold higher yields at 18 than at $28^{\circ} \mathrm{C}$. When compared at $18^{\circ} \mathrm{C}, \mathrm{COR}$ production by $\mathrm{PG} 4180$ was 20 -fold higher than by DC 3000 , whereas both strains produced almost the same amount of COR at $28^{\circ} \mathrm{C}$.

\section{Effect of temperature on cma promoter activity in vitro.}

To analyze COR gene expression, we constructed plasmid pHW01 containing a transcriptional fusion of the cma promoter region from PG4180 to a promoterless egfp gene in the broad-host-range vector pBBR1MCS. It previously was shown in vitro that the cma promoter exhibits a temperature-dependent transcriptional activity (Budde et al. 1998; Ullrich et al. 1994). Enhanced green fluorescent protein (EGFP), a redshifted variant of wild-type (wt)-GFP, was chosen as a reporter because it shows, in contrast to wt-GFP, only small differences in folding efficiency at different temperatures (Patterson et al. 1997). Transcription of cma::egfp in PG4180(pHW01) and DC3000(pHW01) was examined in HSC medium. The growth rates of wild-type strains and strains harboring plasmid pHW01 in HSC medium were similar throughout the 75-h sampling time (Fig. 1A and D). Growth at $18^{\circ} \mathrm{C}$ was considerably slower than growth at $28^{\circ} \mathrm{C}$, with doubling times of approximately $7 \mathrm{~h}$ at $18^{\circ} \mathrm{C}$ and 4 to $4.5 \mathrm{~h}$ at $28^{\circ} \mathrm{C}$. When incubated at $18^{\circ} \mathrm{C}$, the bacteria reached the stationary phase within $60 \mathrm{~h}$, whereas cells grown at $28^{\circ} \mathrm{C}$ reached the stationary phase within 30 to $35 \mathrm{~h}$. All strains reached similar optical densities during the late stationary phase. These results suggested that bacteria were not burdened by EGFP production.

The transcriptional activity of the cma promoter was estimated by measuring EGFP fluorescence of cells harvested at different optical densities (Fig. 1B and E). Autofluorescence of wild-type cells was found to be negligible at the wavelengths used (data not shown). PG4180(pHW01) showed a 10-fold higher maximal fluorescence at 18 compared with $28^{\circ} \mathrm{C}$ (Fig. 1B). During the exponential growth phase, fluorescence of PG4180(pHW01) increased steadily when cells were incubated at $18^{\circ} \mathrm{C}$ and reached maximal values in the early stationary phase $(\mathrm{OD} 600=4.0)$. Fluorescence remained relatively constant until it declined in the late stationary phase $\left(\mathrm{OD}_{600}=6.0\right)$. In contrast, EGFP fluorescence of PG4180(pHW01) incubated at $28^{\circ} \mathrm{C}$ remained low throughout the entire growth of the culture.

Expression of EGFP from the PG4180 $\mathrm{cma}$ promoter in DC3000(pHW01) was highest in the early exponential growth phase and decreased only slightly during growth (Fig. $1 \mathrm{E})$. No temperature effect was observed. The highest fluorescence values of DC3000(pHW01) reached approximately one-third of those measured at $18^{\circ} \mathrm{C}$ for PG4180(pHW01) cultures. This correlates well with the COR production rates of the two strains.

The experiments were repeated with plasmid pHW02, carrying the cma promoter region of DC3000 fused to a promoterless egfp gene. The pattern of EGFP fluorescence during growth of PG4180(pHW02) and DC3000(pHW02) in HSC medium was undistinguishable from those reported for PG4180 and DC3000 containing plasmid pHW01. These results indicate that the cma expression is dependent on the genetic background of the host strain, but both $\mathrm{cma}$ promoters from PG4180 and DC3000 were regulated in a similar manner in a given host strain. 
Effect of temperature

on cma transcript abundance in vitro.

To monitor cma transcript abundance in response to temperature and growth phase, total RNA was prepared from PG4180 and DC3000 grown in HSC medium at 18 and $28^{\circ} \mathrm{C}$ and harvested at different optical densities. The expression of the cma operon was examined by dot blot analysis with 0.5 kb RNA probes specific for $c m a A$. To ensure maximal efficiency of hybridization, total RNA samples of a given strain were analyzed with an RNA probe derived from genomic DNA of the same strain. Quantification of signals revealed a temperature-regulated transcription of the $\mathrm{cma}$ operon in PG4180 but not in DC3000 (Fig. 1C and F). Signal intensities for the cma mRNA in PG4180 were highest during the early exponential growth phase $\left(\mathrm{OD}_{600}=0.5\right)$ and remained on a high level until the early stationary phase $\left(\mathrm{OD}_{600}=4.0\right)$ (Fig. 1C). In contrast, only small amounts of the cma transcript were detected in all samples of total RNA isolated
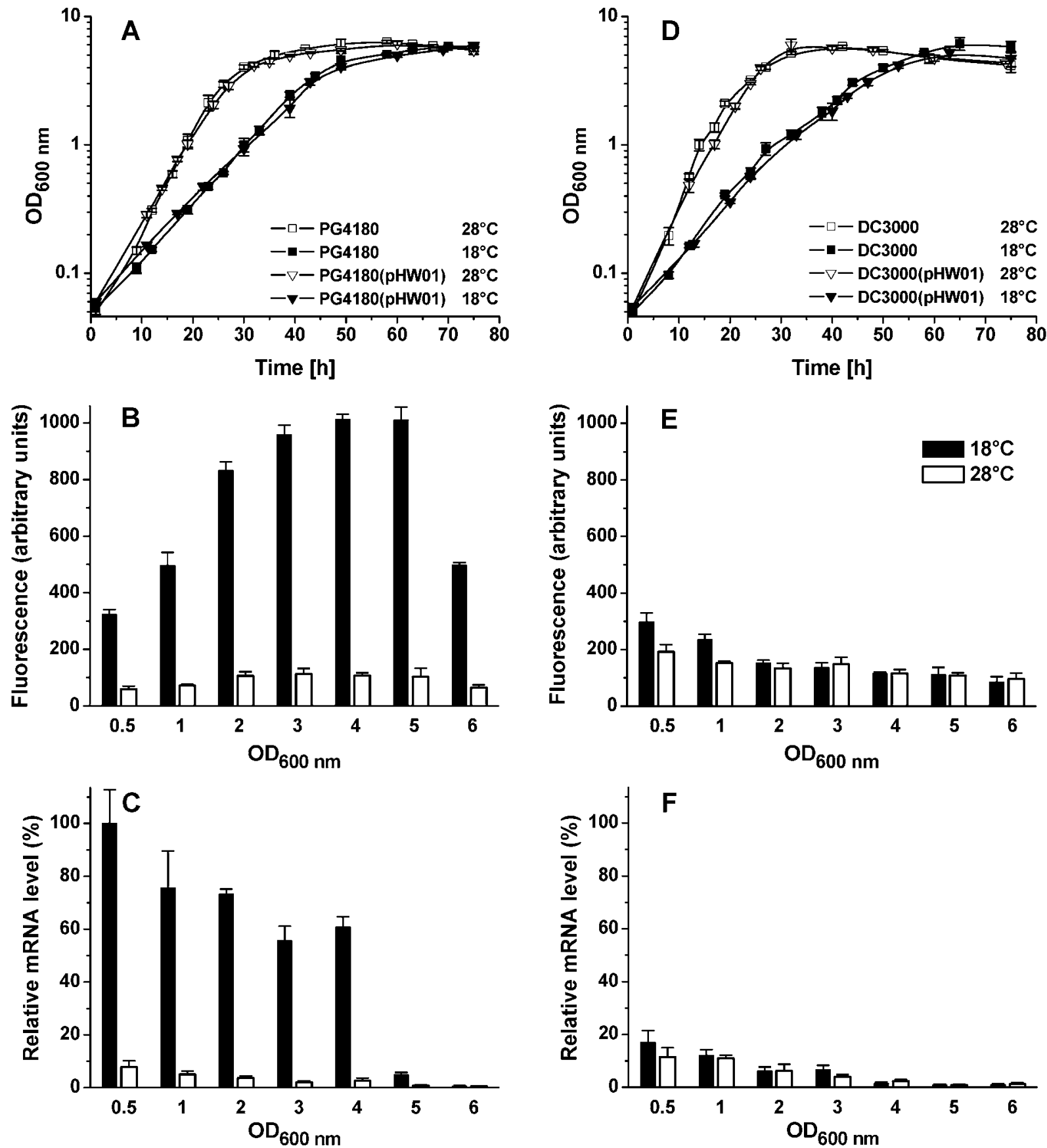

Fig. 1. Temperature effects on bacterial growth, cmaABT promoter activities, and cmaABT transcript abundance in Pseudomonas syringae pv. glycinea PG4180 and P. syringae pv. tomato DC3000. For liquid cultures at 18 or $28^{\circ} \mathrm{C}$, bacteria were grown in Hoitink-Sinden minimal medium optimized for coronatine production. cmaABT promoter activities were determined in fluorescence arbitrary units in transconjugants harboring plasmid pHW01. A, Growth kinetics of PG4180 (squares) and PG4180(pHW01) (triangles) at $18^{\circ} \mathrm{C}$ (filled symbols) and $28^{\circ} \mathrm{C}$ (open symbols). B, Fluorescence of PG4180(pHW01) at 18 and $28^{\circ} \mathrm{C}$. C, Quantitative RNA dot blot analysis for $c m a A B T$ mRNA abundance in PG4180 at 18 and $28^{\circ} \mathrm{C}$. D, Growth kinetics of DC3000 (squares) and DC3000(pHW01) (triangles) at $18^{\circ} \mathrm{C}$ (filled symbols) and $28^{\circ} \mathrm{C}$ (open symbols). E, Fluorescence of DC3000(pHW01) at 18 and $28^{\circ} \mathrm{C}$. F, Quantitative dot blot analysis for $\mathrm{cmaABT}$ mRNA abundance in DC3000 at 18 and $28^{\circ} \mathrm{C}$. The relative mRNA level is related to the highest mean value determined in PG4180, which was defined as $100 \%$. Values represent the means and standard errors of two experiments with three replicates; $\mathrm{OD}_{600}=$ optical density at $600 \mathrm{~nm}$. 
from PG4180 cells grown at $28^{\circ} \mathrm{C}$. At both temperatures, cma mRNA was less abundant in DC3000. The highest signal intensities specific for cma could be detected in DC3000 at both temperatures during the early exponential phase. They reached approximately $20 \%$ of the transcript level observed in PG4180 at $18^{\circ} \mathrm{C}$. The signals decreased slightly throughout the growth of the DC3000 cultures.

Effect of temperature on $\mathbf{c m a}$ promoter activity in planta.

In order to analyze the cma promoter activity in planta, PG4180(pHW01) and DC3000(pHW01) were inoculated into leaves of their respective host plants by infiltration. Subsequently, soybean and A. thaliana plants were kept in growth chambers set to 18 or $28^{\circ} \mathrm{C}$. Three days after inoculation, bacteria were recovered by macerating infected leaf areas. Wild-type strains and transconjugants harboring plasmid pHW01 caused typical disease symptoms and reached similar population sizes when inoculated individually into their host plants (data not shown). These results suggested that bacteria are not burdened by EGFP production even while growing in planta. EGFP fluorescence of bacteria was quantified by CLSM. Fluorescence of recovered bacteria was compared with fluorescence of cells grown in HSC medium and harvested at the optical density at which maximal fluorescence occurred. Analysis of bacteria with CLSM revealed that COR gene expression in PG4180(pHW01) is also tem-
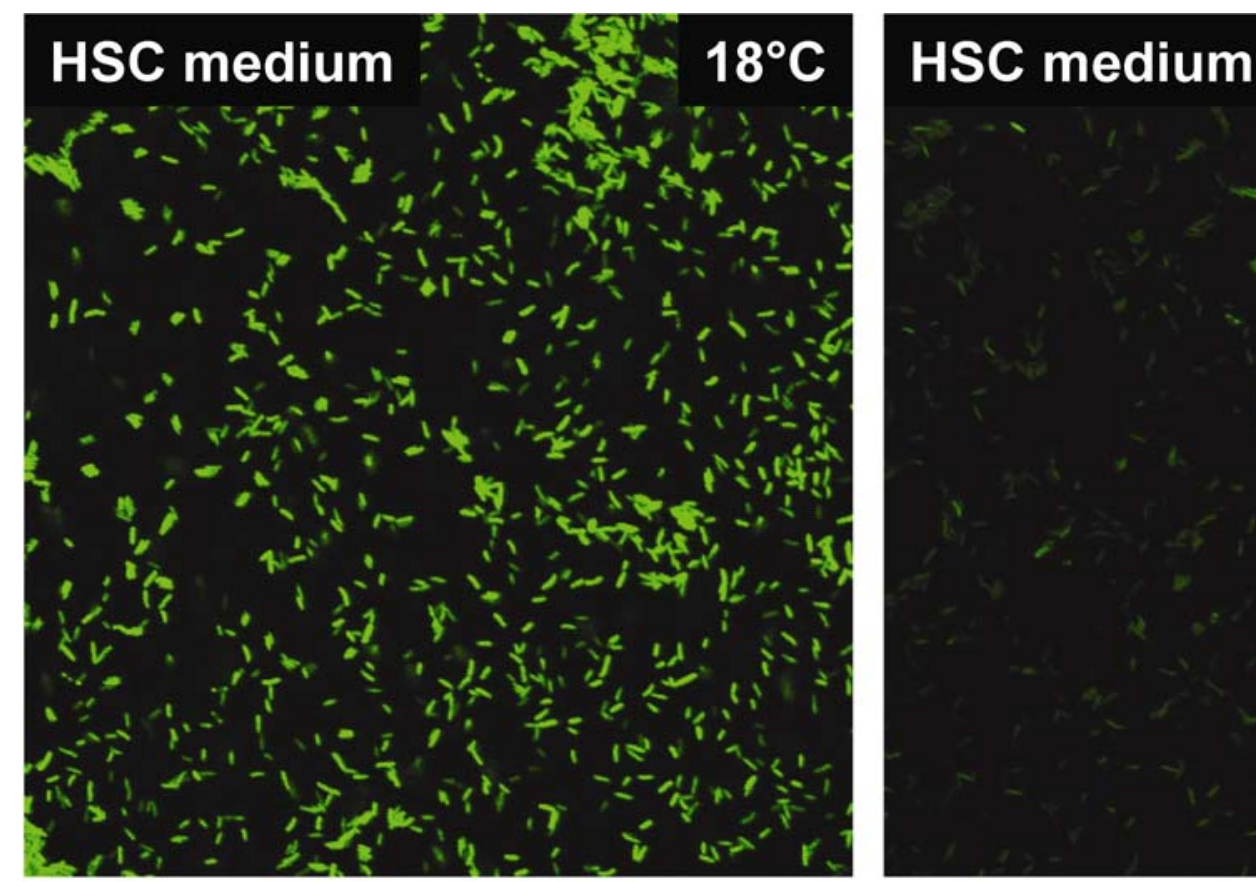

$28^{\circ} \mathrm{C}$
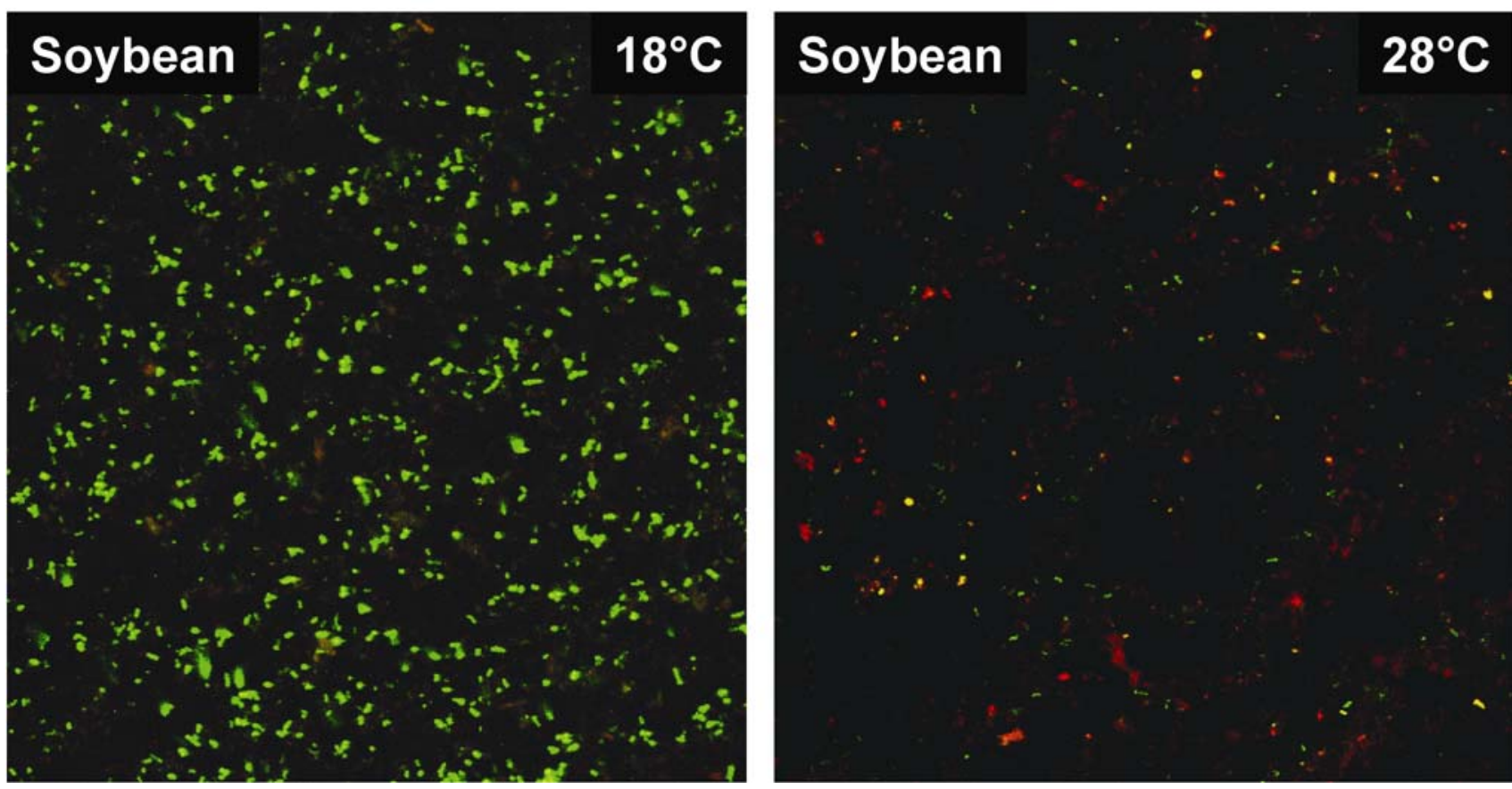

Fig. 2. Fluorescence of Pseudomonas syringae pv. glycinea PG4180(pHW01) in vitro and in planta imaged by confocal laser scanning microscopy. Bacteria were grown in Hoitink-Sinden minimal medium optimized for coronatine production (HSC medium) and harvested at the early stationary growth phase (optical density at $600 \mathrm{~nm}=4.0$ ). To assay fluorescence of bacterial cells in planta, infected soybean leaves were macerated in isotonic $\mathrm{NaCl}$ solution 3 days after inoculation. 
perature-dependent in planta. $\mathrm{PG} 4180(\mathrm{pHW} 01)$ cells recovered from soybean plants kept at $18^{\circ} \mathrm{C}$ showed a strong fluorescence, whereas fluorescence of bacteria from plants incubated at $28^{\circ} \mathrm{C}$ was hardly detectable (Fig. 2). Similar levels of fluorescence were detected in PG4180(pHW01) recovered from soybean plants incubated at $18^{\circ} \mathrm{C}$ and in PG4180(pHW01) grown in HSC medium at $18^{\circ} \mathrm{C}$, indicating that the cma promoter is temperature-sensitive but not plantinducible in this strain.

Interestingly, the opposite was observed for strain DC3000. DC3000(pHW01) recovered from A. thaliana plants showed three- to fourfold higher levels of fluorescence than DC3000(pHW01) grown in HSC medium, and no significant effect of temperature could be detected (Fig. 3). Our results show that COR biosynthesis is differently regulated in these $P$. syringae model strains, possibly reflecting the adaptation to different host plants.

When in planta experiments were repeated with PG4180 and DC3000 containing plasmid pHW02, fluorescence patterns undistinguishable from those reported for PG4180 (pHW01) and DC3000(pHW01) were observed (data not shown). These results supported our earlier notion that expression of cma::egfp fusions derived from either PG4180 or DC3000 entirely depended on the host strain's genetic background but did not show promoter sequence-specific alterations.
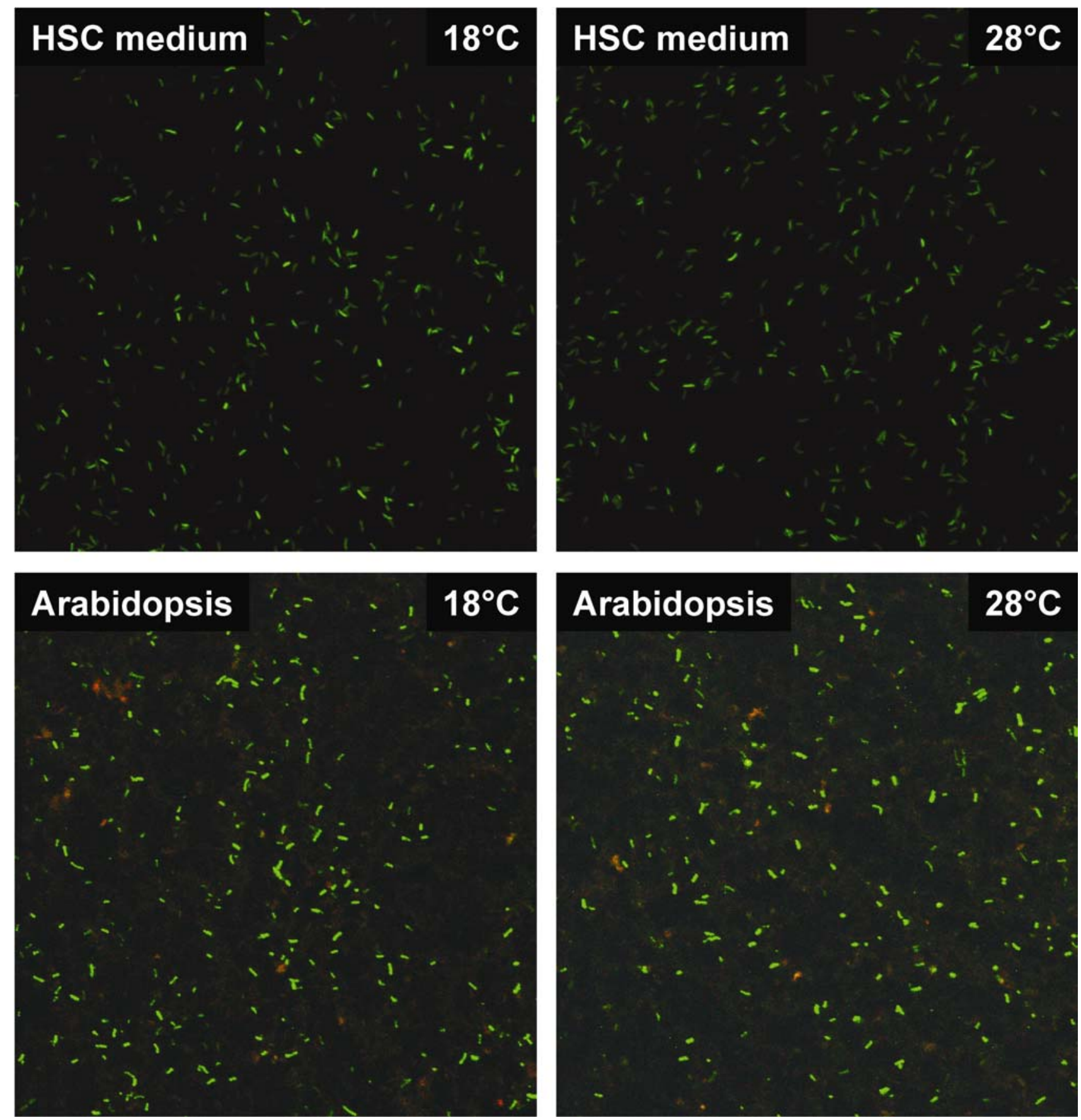

Fig. 3. Fluorescence of Pseudomonas syringae pv. tomato DC3000(pHW01) in vitro and in planta imaged by confocal laser scanning microscopy. Bacteria were grown in Hoitink-Sinden minimal medium optimized for coronatine production (HSC medium) and harvested at the early exponential growth phase (optical density at $600 \mathrm{~nm}=0.5$ ). To assay fluorescence of bacterial cells in planta, infected Arabidopsis thaliana leaves were macerated in isotonic NaCl solution 3 days after inoculation. 


\section{DISCUSSION}

Multiple environmental and nutritional factors impact COR biosynthesis by P. syringae (Li et al. 1998; Palmer and Bender 1993). Temperature has one of the most striking effects on COR production. In this study, we found more than 60 -fold higher production rates in $P$. syringae pv. glycinea PG4180 at 18 compared with $28^{\circ} \mathrm{C}$, confirming previous data (Budde et al. 1998; Palmer and Bender 1993). In contrast, COR synthesis by $P$. syringae pv. tomato DC3000 was only slightly affected by temperature. This finding contradicts previously reported data which describe a temperature dependence of COR production in DC3000 (Rohde et al. 1998). One plausible explanation for this discrepancy might be a confusion of strains in our former study.

The present study was aimed at analyzing the influence of temperature on in vitro and in planta COR gene expression using transcriptional fusions of the PG4180 and DC3000 $\mathrm{cma}$ promoter regions to a promoterless egfp gene. While plant-induced COR gene expression in DC3000 could be confirmed, this study, for the first time, showed that the in vitro temperature dependence of COR gene expression also can be found in planta.

Data reported in this study show that activity of the $\mathrm{cma}$ expression was dependent on the genetic background of the host strain. When monitored in vitro, $\mathrm{cma}$ promoter activity in PG4180 was temperature-dependent, with maximal expression rates at $18^{\circ} \mathrm{C}$ and low activity at $28^{\circ} \mathrm{C}$. In contrast, transcriptional activity was low at both temperatures in DC3000. These results are consistent with those obtained for COR production by these strains and with those obtained for the cma transcript abundance in response to temperature. However, it remains to be addressed why highest EGFP accumulation occurred in the stationary growth phase even though the highest signal intensities for the $\mathrm{cma}$ transcript were found in the early exponential phase. The GFP protein is very stable in bacteria, with a halflive time of more than 1 day in vivo (Andersen et al. 1998). GFP probably accumulates in a cell as long as the promoter is active and it will persist even after the respective promoter is shut down. Therefore, GFP can be used as a reporter of temperature-dependent transcription, because it reflects the overall activity of the cma promoter during cellular growth.

When the thermoresponsiveness of the $\mathrm{cma}$ promoter was monitored in cells of PG4180 and DC3000 recovered from infected plant tissue, patterns of fluorescence similar to that observed in vitro were found (Figs. 2 and 3). Although temperature had a strong impact on expression of the cma operon in PG4180, no temperature effect was observed in DC3000. However, as described by previous reports (Boch et al. 2002; Li et al. 1998; Ma et al. 1991), COR gene expression was induced in DC3000 during growth in the host plant. These results indicate that signals for induction of COR gene expression differ significantly in PG4180 and DC3000.

Recently, Wang and associates (2002) used transcriptional fusions of the $c f l$ promoter regions from PG4180 and DC3000 to uidA, encoding $\beta$-glucuronidase, to investigate the regulation of COR production, with the emphasis on the timing of $c f l$ gene expression. The $c f l$ gene, which encodes coronafacate ligase, is located at the $5^{\prime}$ end of the transcript derived from the $c f l / c f a$ operon and required for COR production (Liyanage et al. 1995b). Consistent with our results, a dependence of $c f l$ expression on the genetic background was reported, with much higher transcriptional activity in PG4180 than in DC3000. However, in contrast to the cma promoters reported herein, the $c f l$ promoter regions from PG4180 and DC3000 exhibited very different expression levels. The maximal activity of the $c f l$ promoter from DC3000 was significantly lower in both host strains.
Interestingly, although the cma promoter regions from PG4180 and DC3000 show 97\% nucleotide identity, only part of the $c f l$ promoter region (502 bp) is homologous to the corresponding region in PG4180 (93\% nucleotide identity). Moreover, the upstream region of the $c f l$ promoter in DC3000 lacks a CorR-binding site (Wang et al. 2002), a sequence motif that is present in PG4180 (Wang et al. 1999). CorR is a positive activator of COR gene expression (Wang et al. 1999) and belongs as a response regulator protein to the modified two-component system CorRPS (Smirnova et al. 2002). This two-component system was shown to be responsible for temperaturedependent activation of COR biosynthetic promoters in PG4180 (Ullrich et al. 1995). The CorRPS two-component system also is present in DC3000, but its role in the regulation of COR transcription in this organism remains to be elucidated.

An especially intriguing question is how signals originating from the plant are integrated in the regulation of COR biosynthesis in DC3000. Interestingly, so far, all COR genes identified as inducible by plant signals were found exclusively in the $c f l / c f a$ gene cluster, although different approaches were used (Boch et al. 2002; Fouts et al. 2002; Li et al. 1998). In the current study and for the first time, we demonstrate that the $\mathrm{cma}$ operon of DC3000 also is regulated by plant-borne signals.

The coordinated regulation of the hrp/hrc system, which is induced by specific plant signals, and the COR gene cluster recently was addressed by analyzing defined hrp mutants in DC3000 (Peñaloza-Vázquez et al. 2000). The results suggest that $\mathrm{HrpV}$, a negative regulator of the $h r p$ regulon, may have a regulatory effect on COR production. Furthermore, Fouts and associates (2002) showed that the expression of COR biosynthetic genes of DC3000, located in the $c f l / c f a$ operon, is controlled by the alternative sigma factor HrpL. However, results of Boch and associates (2002) suggested that $c f a$ gene expression is not directly regulated by HrpL. Consistent with this is the fact that there are no sequences resembling an "Hrp box" in the $c f l$ promoter region (Fouts et al. 2002). In contrast, an Hrp box-like sequence was found upstream of CorR using a computational search for potential Hrp promoters in the genome of DC3000 (Fouts et al. 2002). However, the expectation value of this Hrp promoter candidate is of relatively low significance and the corR gene was not expressed at detectable levels in response to HrpL. Moreover, as mentioned above, the cfl promoter in DC3000 lacks a CorR-binding site. Therefore, a possible HrpL-dependent expression of corR could be responsible for the plant-inducible phenotype of the $\mathrm{cma}$ operon but not for the induction of the $c f l / c f a$ operon by plant-specific signals.

In summary, the presented data demonstrate that temperature is an important environmental factor influencing COR biosynthesis in PG4180. This fact should be considered when the role of COR in the infection of host plants is evaluated. In contrast, COR production by DC3000 is not affected by temperature but induced by plant-specific signals. Our results show that COR biosynthesis is differently regulated in these $P$. syringae model strains, possibly reflecting the adaptation to different host plants. Both the CorS-mediated thermoresponsiveness of COR synthesis in PG4180 and the HrpL/HrpV-mediated plant inducibility of COR gene expression in DC3000 deserve further investigations to dissect the regulatory circuits and cascades governing the production of a phytotoxin, which plays a considerable role in the plant infection process.

\section{MATERIALS AND METHODS}

\section{Bacterial strains and growth conditions.}

The bacterial strains used in this study included Escherichia coli strain DH5a (Sambrook et al. 1989), P. syringae pv. gly- 
cinea PG4180 (Bender et al. 1993), and P. syringae pv. tomato DC3000 (Moore et al. 1989). Pseudomonas strains were maintained routinely on mannitol-glutamate medium (Keane et al. 1970) at $28^{\circ} \mathrm{C}$. For liquid cultures at 18 or $28^{\circ} \mathrm{C}$, bacteria were grown in $100 \mathrm{ml}$ of HSC medium (Palmer and Bender 1993) as described previously (Budde et al. 1998). E. coli cells were grown at $37^{\circ} \mathrm{C}$ on Luria-Bertani medium. Bacterial growth was monitored by measuring $\mathrm{OD}_{600}$. The antibiotic chloramphenicol was used at a concentration of $25 \mu \mathrm{g} / \mathrm{ml}$.

\section{Plasmids.}

Plasmids pHW01 and pHW02 contain fusions of the $\mathrm{cma}$ promoter regions from $P$. syringae pv. glycinea PG4180 and $P$. syringae pv. tomato DC3000, respectively, to a promoterless egfp gene in vector pBBR.EGFP and were used to measure transcriptional activity in $P$. syringae strains. Construction of plasmid pBBR.EGFP was done as follows. The egfp gene was excised from pRcCMV3.EGFP (provided by I. B. Leibiger, Karolinska Institute, Sweden) using ApaI and HindIII. The resulting approximately 760-bp egfp fragment was ligated into ApaI-HindIII-treated pBBR1MCS (Kovach et al. 1994) to create vector pBBR.EGFP. In pBBR.EGFP, egfp is orientated in the opposite direction to the promoter of lac $Z^{\prime}$. From plasmid pMUP31 (Ullrich et al. 1994), a 2.9-kb PstI fragment containing the cma promoter region of PG4180 was obtained and inserted in the PstI site of pBBR.EGFP to yield pHW01. The plasmid pHW02 was constructed by polymerase chain reaction (PCR) amplification of the cma promoter in DC3000 with the primer corP-DC3000-Pst (5'TTTCTGCAGGAGCTCGGCATGGACTACGTA-3') and primer cmaA-DC3000 (5'-GACCACGCTCAGAGATGA-3'). A 2.9-kb PstI fragment containing the cma promoter of DC3000 was inserted into pBBR.EGFP, creating pHW02. Plasmids were mobilized into strains PG4180 and DC3000 by triparental matings with the helper plasmid pRK2013 (Figurski and Helinski 1979).

\section{Quantification of fluorescence levels.}

To assay fluorescence during growth of bacteria in liquid cultures, aliquots of the cultures were harvested at distinct optical densities, centrifuged, suspended in phosphate-buffered saline ( $\mathrm{pH} 7.4$ ), and adjusted to an $\mathrm{OD}_{600}$ value of 0.5. Fluorescence was quantified using a Dynatech Laboratories (Chantilly, VA, U.S.A.) Fluorolite-100 microplate reader set to an excitation wavelength of $470 \mathrm{~nm}$ with emission detection at $516 \mathrm{~nm}$.

\section{Plant material and inoculation procedures.}

Soybean plants (Glycine max (L.) Merr. cv. Maple Arrow) were grown in a greenhouse at 22 to $25^{\circ} \mathrm{C}, 60 \%$ humidity, with supplemental light for a 14-h photoperiod $\left(350 \mu \mathrm{E} \mathrm{m}^{-2} \mathrm{~s}^{-1}\right)$. Arabidopsis plants (A. thaliana (L.) Heynh. ecotype Columbia) were grown in a controlled-environment chamber at $22^{\circ} \mathrm{C}, 80 \%$ humidity, and a photoperiod of $8 \mathrm{~h}$ of light $\left(170 \mu \mathrm{E} \mathrm{m} \mathrm{m}^{-2} \mathrm{~s}^{-1}\right.$; cold white fluorescent light). To study in planta activity of the cma promoter, $P$. syringae pv. glycinea PG4180 and $P$. syringae pv. tomato DC3000 harboring pHW01 and pHW02, respectively, were inoculated in leaves of their cognate host plants. Bacteria were infiltrated into leaves by means of a needleless syringae at $\mathrm{OD}_{600}=0.05$ (approximately $5 \times 10^{7}$ $\mathrm{CFU} / \mathrm{ml}$ ). Following inoculation, plants were transferred to growth chambers at 18 or $28^{\circ} \mathrm{C}$. To recover bacteria 3 days after inoculation, 60 discs (4 $\mathrm{mm}$ in diameter) containing infected leaf tissue from different plants were excised with a cork borer and macerated in $4 \mathrm{ml}$ of isotonic $\mathrm{NaCl}$. All greenhouse experiments were repeated al least three times to confirm reproducibility.

\section{CLSM.}

Fluorescence of bacterial cells was detected with a confocal laser scanning microscope, DMR XE, type TCS NT (Leica, Lasertechnique $\mathrm{GmbH}$, Heidelberg, Germany) using a PLFluotar objective $(\times 63 ; 1.32$; numerical aperture, oil immersion). Images were analyzed with Leica software package TCS NT, version 1.5.451.

\section{RNA dot blot analysis.}

Total RNA was isolated from bacterial cells by acid phenol/chloroform extraction as described by Majumdar and associates (1991). Aliquots of total RNA (200 ng per dot) were transferred to positively-charged nylon membranes (Pall, Dreieich, Germany) using the Minifold I Spot-Blot System (Schleicher \& Schuell BioScience, Dassel, Germany) according to the manufacturer's recommendations. The RNA hybridization probes were generated by in vitro transcription of PCR products. The $c m a A$-specific primers cmaA-fwd (5'-TTTGAG TCGGTCTGCACGCA-3') and cmaA-revT7 (5'-TAATACGAC TCACTATAGGGAGGGCTGTACGTTGTCTACTAG-3') were used to amplify PCR products from genomic DNA of PG4180 and DC3000, respectively. The reverse PCR primer carries the $\mathrm{T} 7$ promoter sequence at its $5^{\prime}$ end. DIG-labeled RNA probes were synthesized by using the Strip-EZ RNA Probe Synthesis and Removal kit (Ambion Europe, Cambridgeshire, U.K.) and digoxigenin-11-UTP (Roche Diagnostics, Mannheim, Germany). The membranes were incubated in hybridization solution (50\% formamide, $7 \%$ sodium dodecyl sulfate [SDS], $2 \%$ blocking reagent, $0.1 \%$ N-laurylsarcosine, $5 \times \mathrm{SSC}[1 \times \mathrm{SSC}$ is $0.15 \mathrm{M} \mathrm{NaCl}$ plus $0.015 \mathrm{M}$ sodium citrate]) at $68^{\circ} \mathrm{C}$ for $16 \mathrm{~h}$. After hybridization, the filters were washed twice for $5 \mathrm{~min}$ at room temperature in $2 \times \mathrm{SSC}$ and $0.1 \%$ SDS, followed by two washes for $10 \mathrm{~min}$ in $0.2 \times \mathrm{SSC}$ and $0.1 \%$ SDS at $68^{\circ} \mathrm{C}$. Finally, hybridization signals were detected by incubation with anti-digoxigenin-AP Fab fragments (Roche Diagnostics) and ECF substrate (Amersham, Freiburg, Germany) using an FLA-3000 phosphoimager (Raytest, Straubenhardt, Germany). Signals were quantified using the manufacturer's image analysis software package.

\section{Isolation and quantification of COR.}

Organic acids were extracted from cell-free bacterial supernatants $(1.5 \mathrm{ml})$, analyzed and quantified for the presence of COR by high-performance liquid chromatography as described earlier (Budde et al. 1998).

\section{ACKNOWLEDGMENTS}

This study was supported by grants from the Max Planck Society and the Deutsche Forschungsgemeinschaft, Germany. We thank Ingo B. Leibiger (Karolinska Institute, Sweden) for providing plasmid pRcCMV3.EGFP and Angela Smirnova for help with the high-performance liquid chromatography analysis. We are grateful to Carol L. Bender, Antje Burse, and Annette Wensing for stimulating discussions.

\section{LITERATURE CITED}

Andersen, J. B., Sternberg, C., Poulsen, L. K., Bjørn, S. P., Givskov, M., and Molin, S. 1998. New unstable variants of green fluorescent protein for studies of transient gene expression in bacteria. Appl. Environ. Microbiol. 64:2240-2246.

Bender, C. L., Alarcón-Chaidez, F., and Gross, D. C. 1999. Pseudomonas syringae phytotoxins: Mode of action, regulation, and biosynthesis by peptide and polyketide synthetases. Microbiol. Mol. Biol. Rev. 63:266292.

Bender, C. L., Liyanage, H., Palmer, D., Ullrich, M., Young, S., and Mitchell, R. 1993. Characterization of the genes controlling biosynthesis of the polyketide phytotoxin coronatine including conjugation between coronafacic and coronamic acid. Gene 133:31-38.

Bender, C. L., Stone, H. E., Sims, J. J., and Cooksey, D. A. 1987. Reduced 
pathogen fitness of Pseudomonas syringae pv. tomato Tn5 mutants defective in coronatine production. Physiol. Mol. Plant Pathol. 30:273-283.

Boch, J., Joardar, V., Gao, L., Robertson, T. L., Lim, M., and Kunkel, B. N. 2002. Identification of Pseudomonas syringae pv. tomato genes induced during infection of Arabidopsis thaliana. Mol. Microbiol. 44:73-88.

Budde, I. P., Rohde, B. H., Bender, C. L., and Ullrich, M. S. 1998. Growth phase and temperature influence promoter activity, transcript abundance, and protein stability during biosynthesis of the Pseudomonas syringae phytotoxin coronatine. J. Bacteriol. 180:1360-1367.

Budde, I. P., and Ullrich, M. S. 2000. Interactions of Pseudomonas syringae pv. glycinea with host and nonhost plants in relation to temperature and phytotoxin synthesis. Mol. Plant-Microbe Interact. 13:951-961.

Cintas, N. A., Koike, S. T., and Bull, C. T. 2002. A new pathovar, Pseudomonas syringae pv. alisaliensis pv. nov., proposed for the causal agent of bacterial blight of broccoli and broccoli raab. Plant Dis. 86:992-998.

Feys, B. J. F., Benedetti, C. E., Penfold, C. N., and Turner, J. G. 1994 Arabidopsis mutants selected for resistance to the phytotoxin coronatine are male, sterile, insensitive to methyl jasmonate, and resistant to a bacterial pathogen. Plant Cell 6:751-759.

Figurski, D. H., and Helinski, D. R. 1979. Replication of an origin-containing derivative of plasmid RK2 dependent on a plasmid function provided in trans. Proc. Natl. Acad. Sci. U.S.A. 76:1648-1652.

Fouts, D. E., Abramovitch, R. B., Alfano, J. R., Baldo, A. M., Buell, C. R., Cartinhour, S., Chatterjee, A. K., D'Ascenzo, M., Gwinn, M. L., Lazarowitz, S. G., Lin, N.-C., Martin, G. B., Rehm, A. H., Schneider, D. J., van Dijk, K., Tang, X., and Collmer, A. 2002. Genomewide identification of Pseudomonas syringae pv. tomato DC3000 promoters controlled by the HrpL alternative sigma factor. Proc. Natl. Acad. Sci. U.S.A. 99:2275-2280

Gnanamanickam, S. S., Starratt, A. N., and Ward, E. W. B. 1982. Coronatine production in vitro and in vivo and its relation to symptom development in bacterial blight of soybean. Can. J. Bot. 60:645-650.

Ichihara, A., Shiraishi, K., Sato, H., Sakamura, S., Nishiyama, K., Sakai, R., Furusaki, A., and Matsumoto, T. 1977. The structure of coronatine. J. Am. Chem. Soc. 99:636-637.

Keane, P. J., Kerr, A., and New, P. B. 1970. Crown gall of stone fruit. II. Identification and nomenclature of Agrobacterium isolates. Aust. J. Biol. Sci. 23:585-595.

Kenyon, J. S., and Turner, J. G. 1992. The stimulation of ethylene production in Nicotiana tabacum leaves by the phytotoxin coronatine. Plant Physiol. 100:219-224.

Kloek, A. P., Verbsky, M. L., Sharme, S. B., Schoelz, J. E., Vogel, J., Klessig, D. F., and Kunkel, B. N. 2001. Resistance to Pseudomonas syringae conferred by an Arabidopsis thaliana coronatine-insensitive (coi1) mutation occurs through two distinct mechanisms. Plant J. 26:509-522.

Koda, Y., Takahashi, K., Kikuta, Y., Greulich, F., Toshima, H., and Ichihara, A. 1996. Similarities of the biological activities of coronatine and coronafacic acid to those of jasmonic acid. Phytochemistry 41:93-96.

Koike, S. T., Henderson, D. M., Azad, H. R., Cooksey, D. A., and Little, E. L. 1998. Bacterial blight of broccoli raab: A new disease caused by a pathovar of Pseudomonas syringae. Plant Dis. 82:727-731.

Kovach, M. E., Phillips, R. W., Elzer, P. H., Roop, R. M., II, and Peterson, K. M. 1994. pBBR1MCS: A broad-host-range cloning vector Biotechniques 16:800-802.

Li, X.-Z., Starratt, A. N., and Cuppels, D. A. 1998. Identification of tomato leaf factors that activate toxin gene expression in Pseudomonas syringae pv. tomato DC3000. Phytopathology 88:1094-1100.

Liyanage, H., Palmer, D. A., Ullrich, M., and Bender, C. L. 1995a. Characterization and transcriptional analysis of the gene cluster for coronafacic acid, the polyketide component of the phytotoxin coronatine. Appl. Environ. Microbiol. 61:3843-3848.

Liyanage, H., Penfold, C., Turner, J., and Bender, C. L. 1995b. Sequence, expression and transcriptional analysis of the coronafacate ligase-encoding gene required for coronatine biosynthesis by Pseudomonas syringae. Gene 153:17-23.

Ma, S.-W., Morris, V. L., and Cuppels, D. A. 1991. Characterization of a DNA region required for production of the phytotoxin coronatine by Pseudomonas syringae pv. tomato. Mol. Plant-Microbe Interact. 4:69-74.

Majumdar, D., Avissar, Y. J., and Wyche, J. H. 1991. Simultaneous and rapid isolation of bacterial and eukaryotic DNA and RNA: A new approach for isolating DNA. Biotechniques 11:94-101

Mitchell, R. E. 1982. Coronatine production by some phytopathogenic pseudomonads. Physiol. Plant Pathol. 20:83-89.

Mitchell, R. E., Young, S. A., and Bender, C. L. 1994. Coronamic acid, an intermediate in coronatine biosynthesis by Pseudomonas syringae. Phytochemistry 35:343-348.

Mittal, S., and Davis, K. R. 1995. Role of the phytotoxin coronatine in the infection of Arabidopsis thaliana by Pseudomonas syringae pv. tomato.
Mol. Plant-Microbe Interact. 8:165-171.

Moore, R. A., Starratt, A. N., Ma, S.-W., Morris, V. L., and Cuppels, D. A. 1989. Identification of a chromosomal region required for biosynthesis of the phytotoxin coronatine by Pseudomonas syringae pv. tomato. Can. J. Microbiol. 35:910-917.

Palmer, D. A., and Bender, C. L. 1993. Effects of environmental and nutritional factors on production of the polyketide phytotoxin coronatine by Pseudomonas syringae pv. glycinea. Appl. Environ. Microbiol. 59:1619-1626.

Palmer, D. A., and Bender, C. L. 1995. Ultrastructure of tomato leaf tissue treated with the pseudomonad phytotoxin coronatine and comparison with methyl jasmonate. Mol. Plant-Microbe Interact. 8:683-692.

Palmer, D. A., Bender, C. L., and Sharma, S. B. 1997. Use of Tn5-gusA5 to investigate environmental and nutritional effects on gene expression in the coronatine biosynthetic gene cluster of Pseudomonas syringae pv. glycinea. Can. J. Microbiol. 43:517-525.

Patterson, G. H., Knobel, S. M., Sharif, W. D., Kain, S. R., and Piston, D. W. 1997. Use of the green fluorescent protein and its mutants in quantitative fluorescence microscopy. Biophys. J. 73:2782-2790.

Peñaloza-Vázquez, A., and Bender, C. L. 1998. Characterization of CorR, a transcriptional activator which is required for biosynthesis of the phytotoxin coronatine. J. Bacteriol. 180:6252-6259.

Peñaloza-Vázquez, A., Preston, G. M., Collmer, A., and Bender, C. L. 2000. Regulatory interactions between the Hrp type III protein secretion system and coronatine biosynthesis in Pseudomonas syringae pv. tomato DC3000. Microbiology 146:2447-2456.

Rohde, B. H., Pohlack, B., and Ullrich, M. S. 1998. Occurrence of thermoregulation of genes involved in coronatine biosynthesis among various Pseudomonas syringae strains. J. Basic Microbiol. 38:41-50.

Sakai, R., Nishiyama, K., Ichihara, A., Shiraishi, K., and Sakamura, S. 1979. Studies on the mechanism of physiological activity of coronatine: Effect of coronatine on cell wall extensibility and expansion of potato tuber tissue. Ann. Phytopathol. Soc. Jpn. 45:645-653.

Sambrook, J., Fritsch, E. F., and Maniatis, T. A. 1989. Molecular Cloning: A Laboratory Manual, 2nd ed. Cold Spring Harbor Laboratory Press, Cold Spring Harbor, NY, U.S.A.

Smirnova, A. V., Wang, L., Rohde, B., Budde, I., Weingart, H., and Ullrich, M. S. 2002. Control of temperature-responsive synthesis of the phytotoxin coronatine in Pseudomonas syringae by the unconventional twocomponent system CorRPS. J. Mol. Microbiol. Biotechnol. 4:191-196.

Ullrich, M., and Bender, C. L. 1994. The biosynthetic gene cluster for coronamic acid, an ethylcyclopropyl amino acid, contains genes homologous to amino acid-activating enzymes and thioesterases. J. Bacteriol. 176:7574-7586.

Ullrich, M., Guenzi, A. C., Mitchell, R. E., and Bender, C. L. 1994. Cloning and expression of genes required for coronamic acid (2-ethyl-1aminocyclopropane 1-carboxylic acid), an intermediate in the biosynthesis of the phytotoxin coronatine. Appl. Environ. Microbiol. 60:28902897.

Ullrich, M., Peñaloza-Vázquez, A., Bailey, A.-M., and Bender, C. L. 1995. A modified two-component system is involved in temperature-dependent biosynthesis of the Pseudomonas syringae phytotoxin coronatine. J. Bacteriol. 177:6160-6169.

Van Gijsegem, F. 1997. In planta regulation of phytopathogenic bacteria virulence genes: relevance of plant-derived signals. Eur. J. Plant Pathol. 103:291-301

Völksch, B., and Weingart, H. 1998. Toxin production by pathovars of Pseudomonas syringae and their antagonistic activities against epiphytic microorganisms. J. Basic Microbiol. 38:135-145.

Wang, L., Bender, C. L., and Ullrich, M. S. 1999. The transcriptional activator CorR is involved in biosynthesis of the phytotoxin coronatine and binds to the $c m a A B T$ promoter region in a temperature-dependent manner. Mol. Gen. Genet. 262:250-260.

Wang, X., Alarcón-Chaidez, F., Peñaloza-Vázquez, and Bender, C. L. 2002. Differential regulation of coronatine biosynthesis in Pseudomonas syringae pv. tomato DC3000 and P. syringae pv. glycinea PG4180. Physiol. Mol. Plant Pathol. 60:111-120.

Weiler, E. W., Kutchan, T. M., Gorba, T., Brodschelm, W., Niesel, U., and Bublitz, F. 1994. The Pseudomonas phytotoxin coronatine mimics octadecanoid signaling molecules of higher plants. FEBS (Fed. Eur. Biol. Soc.) Lett. 345:9-13

Zhao, Y. F., Jones, W. T., Sutherland, P., Palmer, D. A., Mitchell, R. E. Reynolds, P. H. S., Damicone, J. P., and Bender, C. L. 2001. Detection of the phytotoxin coronatine by ELISA and localization in infected plant tissue. Physiol. Mol. Plant Pathol. 58:247-258.

Zhao, Y., Thilmony, R., Bender, C. L., Schaller, A., He, S. H., and Howe, G. A. 2003. Virulence systems of Pseudomonas syringae pv. tomato promote bacterial speck disease in tomato by targeting the jasmonate signaling pathway. Plant J. 36:485-499. 